\title{
Changing Peddling Activities in a Traditional Vegetable Producing Area: The Case of Kamigamo district, Kyoto
}

\author{
HASHIMOTO Akiko \\ Faculty of Humanities and Social Studies, Joetsu University of Education; Joetsu 943-8512, Japan. \\ E-mail:akiko@juen.ac.jp
}

Received July 19, 2013; Accepted May 7, 2014

\begin{abstract}
The activity of peddlers and the characteristics of peddlers' village were analyzed, and the present status of the peddling activities and the features of the peddler's village were clarified. Discussion focused on the factors of why peddling activities continue today in Kamigamo district, Kyoto. The characteristics of peddling activities in Kamigamo district were: 1) Peddling is mainly carried out by women, and agricultural work is done by their husbands. Both the peddlers and customers pass their work on to their daughters-in-law, making it difficult for men to participate. 2) Peddling activities were important to complement the income from rice farming as the peddlers could get money immediately. 3) Peddling is a single-day activity. The peddling activities in the suburban areas involved production activities in residential areas. 4) A relationship of trust is established between the peddlers and their customers beyond the commercial act. The characteristics of agriculture in Kamigamo district were: 1) Considering the fact that Kamigamo district is a suburban area of Kyoto, the farmlands owned by the peddlers are small. Small amounts of various vegetables are grown. 2) The peddling farmers grow various traditional vegetables. The factors contributing to the continued peddling activities are: the peddling farmers maintain small farmlands and continue their agricultural work while urban land use has expanded; and the traditional vegetables that the peddling farmers grow are closely connected to the daily food of ordinary local people.
\end{abstract}

Key words peddling activities, vegetable peddling, Kamigamo district, Kyoto

\section{Introduction}

The purpose of this study is to discuss the characteristics of peddling activities in a suburban area of Kyoto, and to understand the factors contributing to the continued peddling activities in the area. In Kyoto, such peddling activities have taken place since the Heian Period, and the life of the people living in urban areas has been supported by the peddlers from farming and mountain villages, as well as merchants at the market places. Especially in Kyoto during the Middle Ages, women peddlers played an active role. Amino (1973) and Tabata (1998) studied Katsurame who sold ayu (sweetfish) caught in the Katsura River, and Oharame who sold firewood in the urban areas of Kyoto. Furiuri ${ }^{1}$ (direct sales) by Katsurame, Oharame, and Shirakawame, who sold flowers, were also depicted in Rakuchu rakugaizu byobu (a famous old picture of Kyoto on a byobu), and these peddling activities were well known. The peddling activities in Kyoto were active from the Middle Ages until right after World War II. For example, Iwata (1984) and Hashimoto $(2007,2011)$ discussed the status of peddling by Oharame, right after World War II. However, little is known about present peddling activi- ties in Kyoto. Why are peddling activities still conducted on a daily basis in Kyoto?

Studies on peddling activities in Japan have accumulated in folklore and geography. Folklore was the first discipline to focus on such activities. Kitami (1970) reported the origin of transportation, the traditions of the market places, transportation methods, and cultural propagation by the peddlers. Segawa (1971) researched women living in fishing villages in the western part of Japan and indicated that more women undertake peddling activities than men. In recent years, Masuzaki (2000) explained peddling activities in Hakata conducted by Akinaishi (woman fish peddlers) in Shikanoshima, Fukuoka Prefecture. Kobayashi (2005) surveyed the vegetable peddlers and the families of fruit shops in the Shinohara district, which supplies vegetables to Sawara City, Chiba Prefecture. It seems natural that folklore focuses on the peddling activities to study the history of life culture of ordinary people.

Geographic studies on the peddling activities can be categorized into two main studies according to the viewpoint of the researchers. The first study focuses on the behavior of the peddlers. Tokyo peddling, which increased 
rapidly after the Great Kanto Earthquake of 1923, received attention from geographers (Aono 1932, 1933; Ishikawa 1934; Ozaki 1939; Shimizu 1954, and so on). The studies by these geographers were conducted during the height of Tokyo peddling, and focused on clarifying the extent of peddling areas, using the number of peddlers, residential areas of the peddlers and distribution of the peddling areas, but not analyzing the peddling activities qualitatively; including the attribution of individuals, and concrete peddling activities. That is, the peddlers were surveyed to understand the relationship between urban areas and farming villages. The studies tended not to investigate what motivated the peddlers and/or the perspective of the areas in which the peddlers appeared. This resulted in a failure to demonstrate the mechanisms of the appearance of the peddlers.

The second study focuses on the peddler's villages. Mizoguchi (1976) discussed the selling of agricultural products before the Meiji Period, and clothing peddling activities in the early Taisho and Showa periods, in the upland field villages in the Midai River alluvial fan, by focusing on agricultural infrastructure. Mizoguchi found that farming families, who had poor agricultural infrastructure, were more likely to be active in peddling. Nakamura $(1984,1988)$ also focused on the relationship between a fishing village and a farming village, that the peddlers in the fishing village sold fish. He found that the relationship between these two different types of villages collapsed after World War II. He also categorized fishery peddlers into "peddlers from the local fish market" who purchased products at the locally producing area market, and "peddlers from the fish market in the city" who purchased products at the locally consuming area market (Nakamura 1985). He pointed out that "peddlers from the local fish market" appeared because there were almost no employment opportunities other than peddling (Nakamura 1986). Because of criticism of the viewpoint of the first study, the second study focused on the "areas" where the peddlers appeared and discovered the social structure of the peddler's village. Studies on peddling activities peaked with the studies by Mizoguchi and Nakamura. Their studies focused on peddling activities which had already fallen into decline, or had declined during the present market system, and so does not adequately explain the present peddling activities.

In cultural anthropology, there have been studies on continued peddling activities (Tamura 2006; Saji 2008). Tamura surveyed peddling activities in farming villages in suburban areas of Kyoto, and Saji surveyed the suburban areas of Aizuwakamatsu. Both Tamura and Saji concluded that the major factor of continued peddling activities is the trust relationship between the peddlers and their customers. This trust relationship can be seen not only in modern times but also in the past. However, it is impossible to explain the factors of continued peddling activities only by the trust relationship between peddlers and customers.

To clarify the characteristics of the areas where the peddling activities still continue, based on the behaviors of the peddlers and the characteristics of their village, it is necessary to discuss the factors contributing to continued peddling activities through an analysis of their characteristics and of their village. In accordance with the overviews above, this study surveyed peddling activities in Kamigamo district where peddling is practiced in the suburban areas of Kyoto at present. The peddling activities in Kamigamo district started in the Meiji Period, and changed form through the periods of rapid economic growth. First, the characteristics of Kamigamo district are analyzed, as a peddlers' village before the rapid economic growth period. Next, the actual status of peddling activities is studied, their characteristics are discussed and then, the factors of why peddling activities continue today are discussed.

\section{Research Method}

Most of the vegetable peddling activities in the suburban areas of Kyoto are carried out by the farmers, not by professional peddlers ${ }^{2}$. Hence, authorization for peddling is unnecessary, and statistics on the peddling activities is not conducted by any public institution. This study, discussing the changes in peddling activities, requires the acquisition of the actual, detailed information during a certain time segment. From the conditions above, it is difficult to understand peddling activities clearly from a statistical viewpoint, at the present time, as well as in the past. Therefore, this study tries to understand the development of the peddling activities in a multifaceted way, by combining several methods.

First of all, in terms of focusing on the historical development of peddling activities in the study area, women who were engaged in the activities, their families, and the customers, were interviewed. Also, the activity periods of the informant, and the contents of the activities of the parent generation and the grandparent generations were collected. The contents of the interviews were confirmed, and historical materials on the area were accessed in order to clarify aspects of the past that cannot be understood by interview survey. As a basic historical record, 


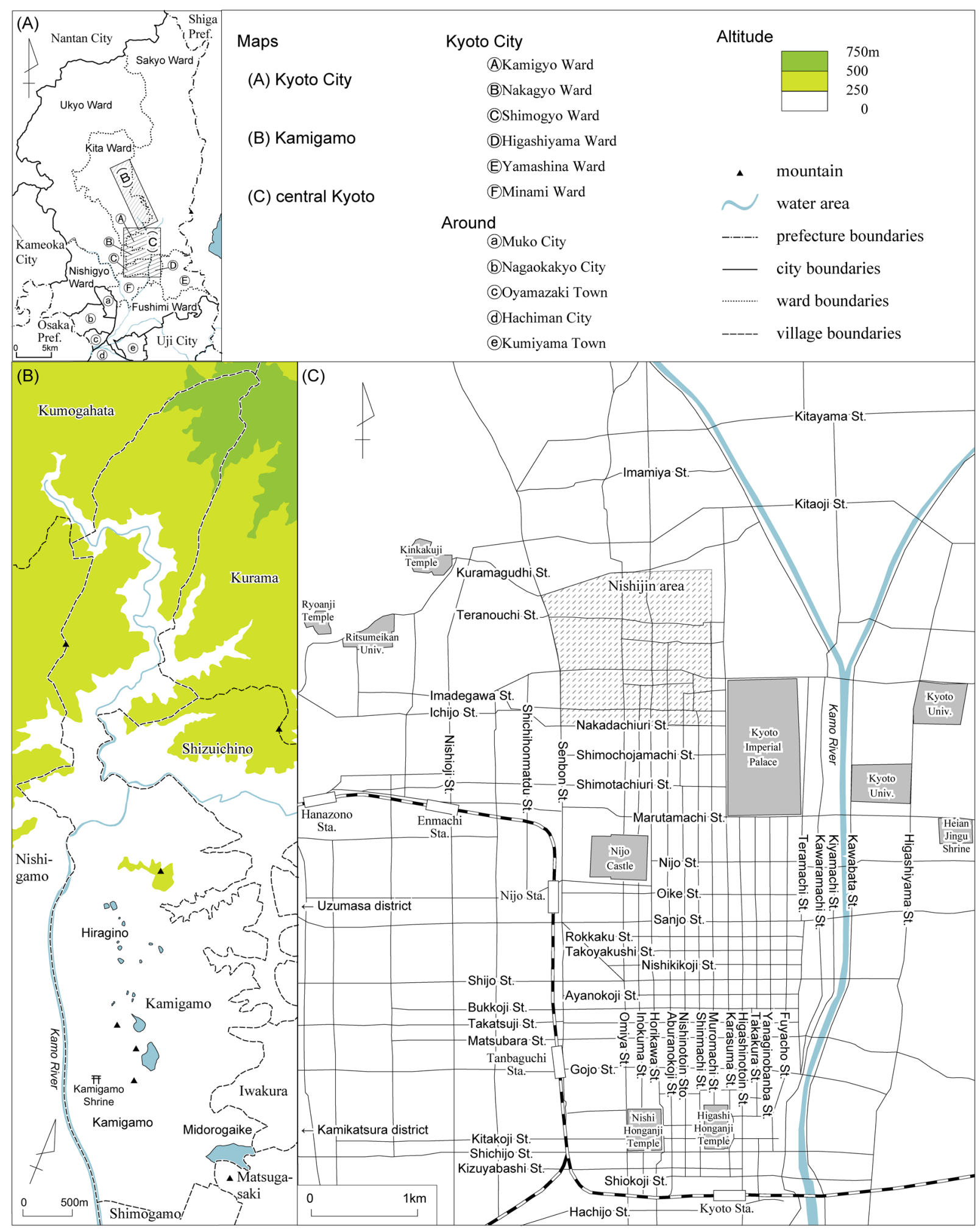

Figure 1. Study area.

Note: Village boundaries and place names based on topographical maps (1912), ward boundaries are current.

Otagi gun son shi (Topography of Otagi County) edited from 1881 to 1884 was used. This record was collected and compiled through village public offices, and it provides comparative information on the area's society and economy during the middle of the Meiji Period ${ }^{3}$.

Secondly, this study focuses not only on the women performing the peddling activities, but also on fam- ily labor, where the peddling activities of women is positioned. The whole image of the study area was understood from the statistical viewpoint using agricultural statistics and the national census, and then combined with discussion of management on a per-household basis, combination of work, and forms of division of labor in the family as understood from the interviews. 
Lastly, this study sees the peddling activities by women as a traditional form of communication, connecting urban areas to suburban areas, and focuses on consideration of the connection with urban areas, changes in the suburban areas, as well as production activities. I accompanied women who are active in peddling activities, as well as interviewing women who are retired from the peddling activities, to show their ranges and their routes.

The target region of this study is the Kamigamo district of Kita ward, Kyoto (Figure 1). The central community of Kamigamo spreads around the Kamigamo Shrine, and the Kamigamo area is thought to have been founded by people who served the Kamigamo Shrine. Two more villages (Hiragino and Midorogaike) were established in 1662. In this paper, I collectively refer to these three villages as the Kamigamo district and refer to each individually as the Kamigamo area, Hiragino area, and Midorogaike area. There are several large ponds in the Kamigamo district, including Midorogaike Pond and Koike Pond. Rice cultivation in paddy fields has generally been observed since the Edo Period.

There are no academic surveys of peddling activities in the Kamigamo district. In this study, I utilized several reports on vegetable production and vegetable peddling, such as a report of Kita ward (Kyoto City 1972b), and reports on the history of vegetable production around Kyoto by Hayashi $(1963,1966)$. My field surveys were mainly performed between 2008 and 2011.

In this study, central Kyoto mainly includes the territories of Kamigyo and Shimogyo wards in 1879, namely an area surrounded by three streets (Kitaoji to the north, Hachijo to the south, and Senbon to the west) and the Kamo River to the east.

Vegetable peddling by women in the Kamigamo district can be thought of as beginning in the Meiji Period. Although vegetable peddling continues to the present day, the form of peddling activity was transformed during the period of high economic growth. Therefore, firstly, I examine the regional characteristics of Kamigamo as a peddlers' village, before the period of high economic growth. Secondly, I examine the transformation process of peddling activities through the period of high economic growth. Lastly, I examine present day farming and peddling activities.

\section{Study Area}

\section{Farming activities before the period of high economic growth}

The commercial production of vegetables began in the Kamigamo district during the Meiji Period (Hayashi 1963). Before the Meiji Period, although suguki (a type of turnip) pickles were grown on small farmlands principally by shake (people who worked for the Kamigamo Shrine), paddy fields dominated the land use of the district (Kyoto City 1972a). The cultivation of suguki spread also to farmers around the Kamigamo Shrine through the close and dependent relationship between farmers and shake in the late Edo Period (Hayashi 1963). Farmers around the Kamigamo Shrine began to grow suguki as an after-crop of rice during the middle of the Meiji Period. In particular, after a big fire in the Midorogaike area in 1893, farmers began to actively sell suguki pickles in central Kyoto to support the reconstruction of their village (Hayashi 1980).

Table 1 shows the situation of rural inhabitants in the Kamigamo district based on a historical document published in 1881 (Otagi gun son shi). Approximately 63.2\% of 633 households were engaged in agriculture growing vegetables such as watermelons, eggplants, Japanese radishes, turnips, suguki, and junsai ${ }^{4}$. According to this document, most women were involved in peddling these agricultural products in addition to farming them. Hence, it can be considered that many households began peddling activities during the Meiji Period. However, because

Table 1. Population and agriculture of the Kamigamo district during the Meiji Period (1881)

\begin{tabular}{|l|c|}
\hline \multicolumn{1}{|c|}{ Classification } & Number \\
\hline Households & 633 \\
\hline Population & 3,117 \\
\hline Rice field & 122 ha \\
\hline Dry field & 40 ha \\
\hline Cattle and horses & 118 \\
\hline Products & \\
Japanese radish & $56 \mathrm{t}$ \\
Turnip & $46 \mathrm{t}$ \\
Suguki & $37 \mathrm{t}$ \\
Watermelon & $28 \mathrm{t}$ \\
Eggplant & $26 \mathrm{t}$ \\
Bacteria of mushroom & $560 \mathrm{~kg}$ \\
Junsai & $750 \mathrm{~kg}$ \\
Sweetfish & 2,500 \\
Little bird & 15,000 \\
Tile & 65,000 \\
Leaf of green tea & $1,740 \mathrm{~kg}$ \\
\hline Job (men) & Earming: about 400 \\
\hline Job (women) & dling activities. \\
\hline Source: Otagigun sonshiculture and ped- & \\
\hline
\end{tabular}

Source: Otagi gun son shi (1881). 
farmland was mostly owned by shake, these peddling households were tenant farmers until the enactment of the Land Reform in 1947. The cost of tenancy was relatively high because farmland was utilized for double cropping (Hayashi 1963). Although the numbers of owner-farmers and shake are unknown, many tenant farmers can be considered to have paid their charges by obtaining additional income from vegetable peddling ${ }^{5}$.

During the Taisho Period, under the economic boom that followed World War I, suguki cultivation was expanded; at the same time, a triple-cropping system was established in which summer vegetables were cultivated in addition to suguki and rice (Hayashi 1963). At that time, suguki pickles were shipped to the markets of Osaka, Nagoya, and Tokyo, resulting in the decline of suguki peddling (Koike 1955). According to an interview with an elderly woman in her eighties, triple cropping was carried out in the Kamigamo district until the 1970s. In this triple cropping, farmers grew various summer vegetables such as onions, potatoes, eggplants, cucumbers, tomatoes, haricot beans, and Japanese pumpkins. After the vegetable crop, rice cultivation was carried out from June to September mainly for domestic use. Following the rice harvest, winter vegetables such as suguki, Japanese radishes, and Chinese cabbage were cultivated until December.

Table 2 shows the numbers of owner farms and tenant farms, in addition to the number of full- and part-time farms, immediately following the 1947 Land Reform. At that time, the number of owner farms and owner/tenant

Table 2. Farm structure of the Kamigamo district after postwar agrarian reform (1956)

\begin{tabular}{|l|c|}
\hline \multicolumn{1}{|c|}{ Types } & Households \\
\hline Land tenure* $^{*}$ & 185 \\
Owner farms & 149 \\
Owner/tenant farms & 25 \\
Tenant/owner farms & 5 \\
Tenant farms & \\
\hline Off-farm jobs** & 321 \\
Full-time farms & 16 \\
Part-time farms (grade 1) & 27 \\
Part-time farms (grade 2) & \\
\hline
\end{tabular}

* The rate of the owned land to the farmland.

Owner farms: 90\%

Owner/tenant farms: $50 \sim 89 \%$.

Tenant/owner farms: 10 49\%.

Tenant farms: 9\%.

** Part-time farms (grade 1), which earn more from farming than other jobs.

Part-time farms (grade 2), which earn more from other jobs than farming

Source: Hayashi (1963). farms made up more than $90 \%$ of the total farms. There were still tenant farms and tenant/owner farms, but they accounted for less than 10\%. According to the 1955 census, the number of households in the Kamigamo district was 1,501-approximately 2.4 times the population in 1881 (633 households). In the same period, the number of farm households decreased slightly, from approximately 400 to 364 . The rapid increase of nonfarm households in this period is striking.

Hayashi (1963) compared the farming activity of Kamigamo and Matsugasaki in 1908 with that of 1956. In 1956 full-time farms made up approximately 88\% of the total farms in Kamigamo, whereas in Matsugasaki the number dropped sharply to $8 \%$ during the same period. Hayashi explained that this was because farm household income was stabilized in Kamigamo by the rapid development of suguki cultivation from the Taisho Period to the early Showa Period. The average farmland size in Kamigamo was 0.44 ha in 1960 (Hayashi 1963), which was nearly equal to the average farmland size in the rural areas around Kyoto. Hayashi pointed out that the average farmland size in the 38 rural districts around Kyoto was 0.43 ha.

\section{Beginning of vegetable peddling}

The origin of vegetable peddling in the Kamigamo district is uncertain. Vegetables were already cultivated in rural villages around Kyoto during the Edo Period (Kyoto City 1972a). Although standing markets of vegetables were opened in Tonya-machi, Chudoji, and Fudodo during the Tensho Period (1573-1592), farmers sold their vegetables directly to their urban customers at farmers' markets (noichi) (Kyoto City 1972a). From the Meiji 30s to the Meiji 40s (1897-1916), farmers' unions and cooperatives were established in each town and village in the prefecture of Kyoto, and cooperative shipping and marketing began (Kyoto City 1975). It seems that the vegetables and suguki cultivated in the Kamigamo district during this period were sold not only at farmers' markets (noichi), but also by peddling (furiuri) in the urbanized areas of Kyoto.

Kyoto City (1975) recorded the starting points for vegetable peddling and the positions of public and periodic markets at the end of the Taisho Period. As for vegetable peddling in Kamigamo, three starting points were indicated: the intersections of Kuramaguchi Street and Teramachi Street, Kuramaguchi Street and Shinmachi Street, and Kuramaguchi Street and Omiya Street (refer to Figure 1). From these starting points, the vegetable peddlers of Kamigamo would have itinerated in a southward 


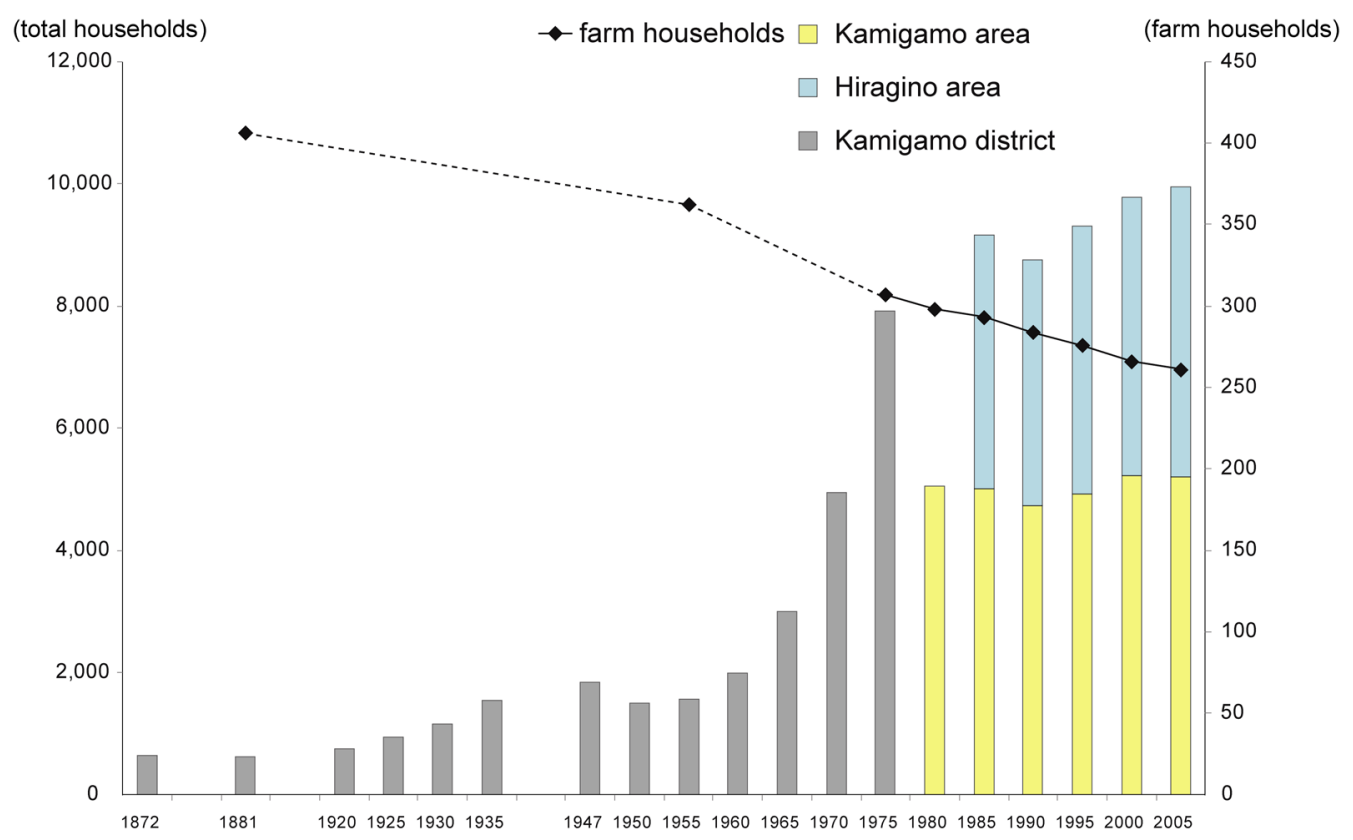

Figure 2. Changes in the number of farm households and total households in the Kamigamo district (1872-2005). Note: 1. Household data in the Hiragino area in 1980 is missing. 2. Data in the Kamigamo area contains household data of the Midorogaike area. Source: Shichoson gappei shi (1872), Otagi gun son shi (1881), population census, Hayashi (1963), and the census of agriculture and forestry.

direction through central Kyoto. These peddling activities by Kamigamo farmers around the north district of the Imperial Palace continued until the 1990s.

\section{Urbanization of Kamigamo district and decline of the Nishijin area}

Population increase and a reduction of farmland were important changes that occurred in the Kamigamo district. Figure 2 shows the evolution of the number of farm households and total households in Kamigamo. Figure 2 also shows that the population of Kamigamo rapid change between 1960 and 1975. Corresponding with this population increase, a land readjustment project for urban development occurred between 1963 and 1973 in the Kamigamo and Midorogaike areas, affecting 65 ha of farmland owned by 290 farmers. Additionally, in the Hiragino area, athletic facilities were constructed in the late 1960s for Kyoto Sangyo University and Ritsumeikan University. With the reduction of farmland, part-time farms increased in the Kamigamo district. As mentioned earlier, most farm households were full-time farms in 1956 (321 of 364 households), whereas in 1973 only 28 of 307 households remained full-time. In 2008, 62 fulltime farms were in operation (24.5\%) as opposed to 191 part-time farms (75.5\%). As I'll discuss later, farmers who want to continue farming have obtained farmland in areas other than the Kamigamo district.

It is important to note the decreasing importance of the Nishijin area (refer to Figure 1) as a market area. Until the 1960s, Nishijin was a major destination of peddlers because the area had a large number of customers including weavers of Nishijin textile, which means that a large population provided enough organic manure (Takano 2009). Since the collection of organic manure in central Kyoto was remunerated ${ }^{6}$, this provided additional and incidental revenues for rural farmers. The textile industry of Nishijin peaked between 1978 and 1990 (Uemura 2004). Therefore, until around 1990, Nishijin was by far the most important market for Kamigamo vegetable peddlers. The decline of the Nishijin textile industry and the aging of Nishijin's inhabitants brought about significant changes in the itinerant routes and regular customers of Kamigamo peddlers.

\section{Continuation Process of Peddling Activities}

\section{Changes in production methods, transport, and peddling territories}

Agricultural instruments were mechanized during the period of high economic growth, mainly from the late 1950s through the 1970s. Farmers' working hours were shortened, and the variety of vegetables increased. A farmer in his sixties in the Hiragino area told me his father purchased a cultivator as his first farming machine in 1957. Until then, his father had cultivated his rice fields with a hoe and a plow pulled by cattle. From the late 1960 s to the 1970s, his father purchased a tractor, a pump for scattering water, a machine for rice harvest- 
ing, a machine for binding, a dryer machine, and a riceplanting machine. In addition, he purchased a spraying machine for chemicals and a washing machine for vegetables in 1965 and another small cultivator in 1976. Before mechanization, farmers spent many hours performing all farming activities by hand. Incidentally, the first farming machine in the Kamigamo district, a cultivator, was purchased for 240,000 yen in 1954.

Mechanization enabled Kamigamo farmers to grow a wider variety of vegetables. According to a woman in the Hiragino area, the volume of vegetables carried by women peddlers did not change significantly between her mother's generation and her own. However, the variety of vegetables approximately doubled.

According to a 1971 survey of Kita ward, Kyoto City, most vegetable peddlers (72.2\%) sold four to six kinds of vegetables (Kyoto City 1972b). According to my interview surveys, the average number of vegetable types sold by Kamigamo peddlers - who generally peddle between April and August-was 8.9 in 2010. Among the peddlers of the Hiragino area-who generally peddle year-roundthe average number of vegetable types was 11.2 for the same period.

Table 3 shows the means of transportation and the extent of peddling territories have changed. For example, a woman peddler from household number 50 was married at the age of 22 in 1951. Although she grew up in a farm household, she was not involved in farming before her marriage. Just after her marriage, her mother-in-law taught her about farming and peddling activities. Since her mother-in-law kept her customers, the woman had to find her own customers in the Nishijin area by herself. In 1952, she acquired a driver's license. During the 1950s and 1960s, many women peddlers in Kamigamo acquired driver's licenses and changed their means of transport from two-wheeled carts to pickup trucks. All eight women peddlers in Table 3-a transport vegetables with their own pickup trucks. However, a few women peddlers in Kamigamo still carry their vegetables by twowheeled cart. The changes in peddling territories during this period can mostly be attributed to this change in the means of transport.

The changes in peddling territories are clearly shown by several examples of women peddlers in Table 3. Most

Table 3. Peddling activities of eight case study farms in the Kamigamo and Hiragino areas

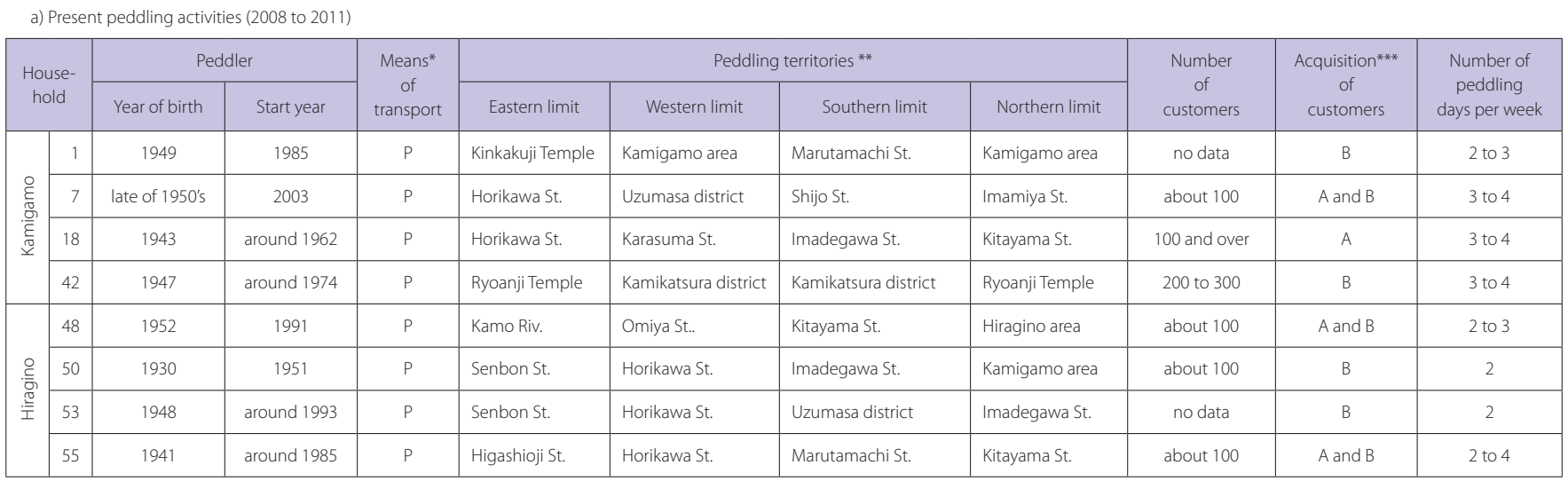

b) Peddling activities of one generation ago (1940s to 2008)

\begin{tabular}{|c|c|c|c|c|c|c|c|}
\hline \multirow{2}{*}{\multicolumn{2}{|c|}{$\begin{array}{l}\text { House- } \\
\text { hold }\end{array}$}} & \multicolumn{3}{|c|}{ Peddler } & \multirow{3}{*}{$\begin{array}{c}\begin{array}{c}\text { Means of * } \\
\text { transport }\end{array} \\
\text { C to P }\end{array}$} & \multirow{3}{*}{$\begin{array}{l}\text { Peddling territories** } \\
\text { Nishijin area }\end{array}$} & \multirow{3}{*}{$\begin{array}{c}\begin{array}{c}\text { Number of } \\
\text { peddling } \\
\text { days per week }\end{array} \\
\text { unknown }\end{array}$} \\
\hline & & \multirow{2}{*}{$\begin{array}{l}\text { Relation }{ }^{* * * *} \\
\text { Mother-in-law }\end{array}$} & \multirow{2}{*}{$\begin{array}{c}\text { Year of birth } \\
1921\end{array}$} & \multirow{2}{*}{$\begin{array}{c}\text { Period } \\
\text { unknown to } 1984\end{array}$} & & & \\
\hline \multirow{4}{*}{ 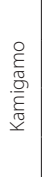 } & 1 & & & & & & \\
\hline & 7 & Mother-in-law & 1927 & 1949 to 2008 & C to $P$ & Nishijin area & 2 to 3 \\
\hline & 18 & Mother-in-law & unknown & unknown to 1997 & $C$ to $P$ & around Shinmachi St. & 4 to 5 \\
\hline & 42 & Mother-in-law & around 1924 & unknown to 1984 & $C P$ to $C$ & Nishijin area & 4 to 5 \\
\hline \multirow{4}{*}{ 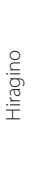 } & 48 & Mother-in-law & 1926 & unknown to 1994 & c & Kamigamo district to Kitayama St. & 2 to 3 \\
\hline & 50 & Mother-in-law & unknown & unknown & $C$ to $P$ & unknown & 2 \\
\hline & 53 & Mother-in-law & 1924 & 1947 to 1993 & c & Nishijin area & 3 \\
\hline & 55 & Mother-in-law & unknown & unknown & c & Nishijin area & 2 to 3 \\
\hline
\end{tabular}

*C signifies two-wheeled carts, P signifies pickup trucks, and CP signifies shoulder carrying pole.

** Figure 1 shows districts and streets.

*** A signifies that present peddlers succeeded the customers from their mother-in-law, and B signifies new customers only.

**** Relation of present peddler and peddler of one generation ago.

Note: Household number of this table corresponds with that of Figure 3

Source: Interview surveys. 
women peddlers of the previous generation had their principal customers in the Nishijin area (Table 3-b). Until about 1990, the peddling territories for Kamigamo peddlers were mostly limited to the Nishijin area. According to a woman peddler of the previous generation, there were many small textile factories in the Nishijin area until approximately 1990. Since many women weavers were employed in these factories, vegetable peddlers could sell their commodities in large quantities at each factory. Although peddlers of the present generation may still visit old customers in the Nishijin area, they no longer sell such large quantities of vegetables. Because of these changes in Nishijin, vegetable peddlers in Kamigamo had to find new customers in other areas. A woman peddler of the younger generation (household number 7), for example, extended her peddling territory westward into the Uzumasa area and southward to Gojo Street. The peddling territories of the present generation typically extend to the Kamigamo district to the north, Imadegawa Street to the south, Karasuma Street to the east, and Senbon Street to the west (Table 3-a). Peddlers in the Kamigamo district have gained new customers mainly through personal efforts, extending their peddling territories individually.

\section{Farming activities of peddling households in the present}

The techniques for processing suguki pickles have traditionally been inherited in each household and remain secret even now. Farmers who cultivate and process suguki are rare in the Nishigamo district and the Hiragino area; thus, it seems that the production of suguki pickles was restricted to the Kamigamo area and the Midorogaike area around the Kamigamo Shrine. Currently, two different systems of double-cropping are observed in the Kamigamo district: summer vegetables and winter suguki for Kamigamo and Midorogaike, and summer vegetables and winter vegetables for Hiragino.

In 2008, the Kamigamo district included 253 farm households. Of these, 62 were full-time farmers, and 191 were part-time farmers. In addition, 102 of those 253 farms were involved in rice cultivation as the main source of revenue, whereas vegetable cultivation was dominant for the other 151 farms (Kyoto City 2009). According to the 2005 census, the number of households in the Kamigamo district was 5,192. Therefore, farm households comprised $4.9 \%$ of all households. Although vegetable peddlers can be observed frequently in central Kyoto, they are not registered with any governmental institutions-including public hygienic organizations-so their precise numbers and distribution cannot be determined from public statistics. In my field surveys, I confirmed that 55 vegetable peddlers existed in the Kamigamo district, which accounted for $22 \%$ of the farm households in the district.

Figure 3 shows the farming activities of these 55 peddling households in the Kamigamo district. In these peddling farms, the husband and wife are mainly engaged in agriculture, sometimes with other family members. In 34 of these farms, there are successors of the farming enterprise, which represent more than $60 \%$ of the total. The average cultivated area is 0.5 ha. Farms larger than 0.5 ha are seen as large by inhabitants of Kamigamo and Midorogaike. Among these 55 peddling households, the largest farm is a Kamigamo farm (household number 16) with 1.3 ha of cultivated area.

Regarding household income, 39 peddling farms in the Kamigamo and Midorogaike areas obtain some income from the sale of suguki pickles. In the 1930s, suguki pickles generated six times the income of summer vegetables (Koike 1955); however, the two products currently yield similar incomes. As for rice cultivation, only 16 peddling farms in Kamigamo and Midorogaike obtain income from the sale of rice, while in the Hiragino area, almost all peddling farms cultivate and sell rice. Therefore, household income in the former areas comes mainly from the sale of vegetables and suguki pickles, while vegetable and rice cultivation contribute to household income in the latter area.

Fifty peddling households earn income from real estate activities. Since the southern part of Kamigamo is designated as a zone of urbanization in urban land use policy, a high-level tax-equivalent to that of an urbanized area-is applied to farmland inside the zone. Some farmers, therefore, transform part of their farmland into rental apartments or simply sell part of the land to urban developers. In some cases, these transitions to urban land use are precipitated by the deterioration of the surrounding agricultural environment. In contrast, in the Hiragino area, most farmland is designated as a zone of restriction for urban development. Many farmers nevertheless gain some real estate income by building apartment housing for university students.

As for peddling activities, there are 58 peddlers in these 55 households -52 women and 6 men. The peddlers of households 17, 30, 40, and 49 are men, but in the great majority of households, peddling activities are performed by women. There are 2 peddlers in their thirties, 2 in their forties, 16 in their fifties, 16 in their sixties, 10 in their seventies, and 12 in their eighties. Peddlers in their fifties 


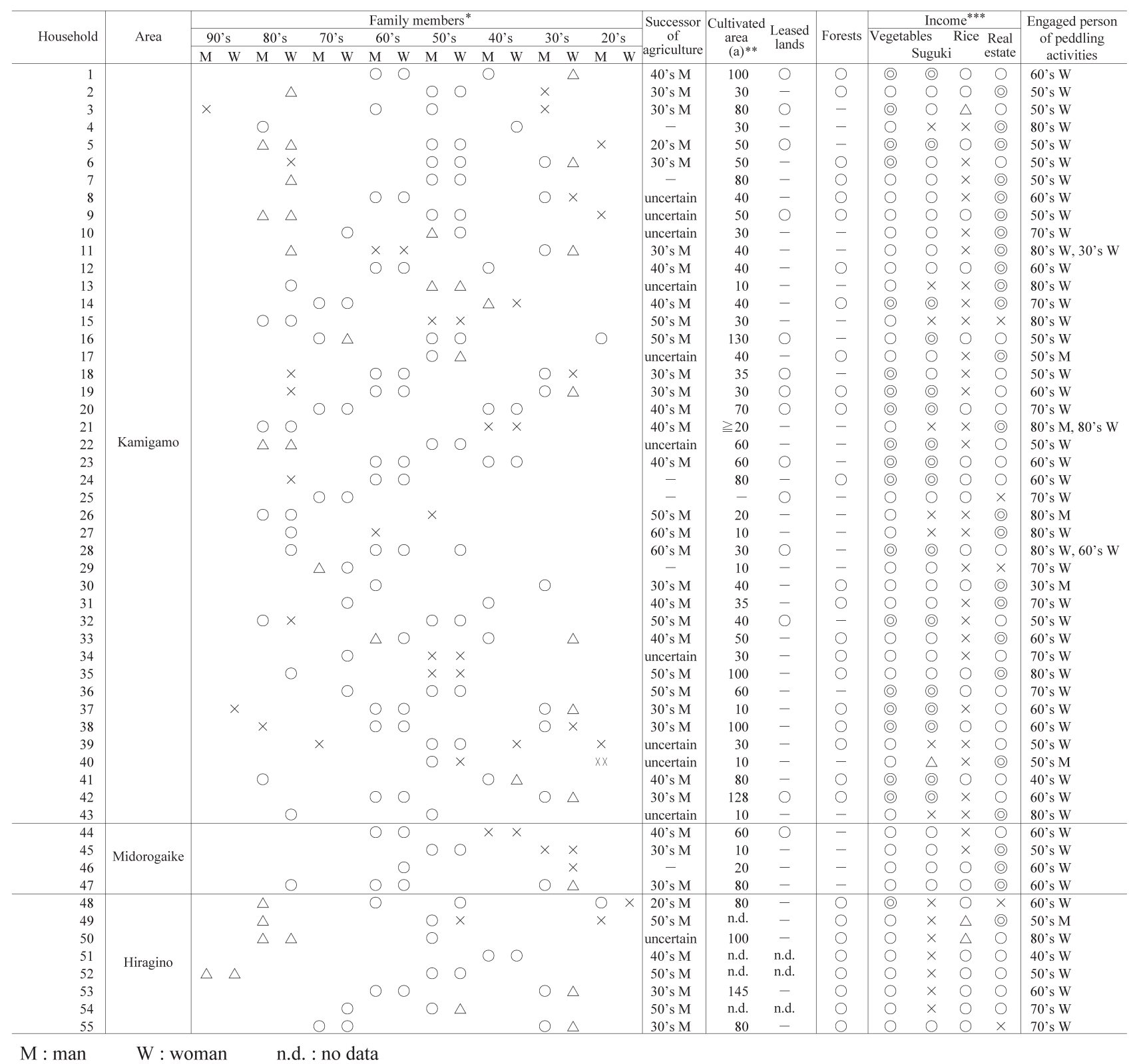

Figure 3. Farming activities of 55 peddling households in the Kamigamo district (February 2011).

* Signs show the degree assigned to agriculture. $\bigcirc$ : always, $\triangle$ : occasionally, $X$ : not engaged in.

** Numerical values are round numbers.

*** Signs show the importance for total income for peddling households.

( ): high, $\bigcirc$ : middle, $\triangle$ : personal use, $X$ : non income.

Source: interview surveys.

and sixties account for approximately 55\% of all peddlers. Men formerly began to help farming at approximately 20 years of age, and their wives began farming and peddling immediately following marriage. Currently, however, it is common for young men and women to be engaged in offfarm jobs. They begin farming after their parents become elderly and retire. This explains why the majority of peddlers in this study were over 50 .

Peddling households sell vegetables through means other than peddling. For example, seven peddling farms in Kamigamo established contracts with a cooperative society to sell their commodities. Some peddling farms contract with supermarkets. Peddlers may also sell their commodities at a noichi, a farmers' market. Some peddlers periodically sell vegetables at a noichi, while other peddlers bring their remaining vegetables there after peddling.

Table 4 shows the farming and sales methods for eight peddling households in the Kamigamo and Hiragino areas. Concerning farmland use, all peddling farms in the Kamigamo area cultivated more dry-field areas than ricefield areas. Cultivating various vegetables in dry fields is very time consuming while much less work is needed for rice cultivation. Therefore, farmers generally use neigh- 
Table 4. Farming and peddling activities of eight case study farms in the Kamigamo and Hiragino areas (August 2010)

\begin{tabular}{|c|c|c|c|c|c|c|c|c|c|c|c|c|c|c|c|c|c|c|}
\hline \multirow{3}{*}{\multicolumn{2}{|c|}{$\begin{array}{c}\text { House- } \\
\text { hold }\end{array}$}} & \multicolumn{4}{|c|}{ Rice field } & \multicolumn{4}{|c|}{ Dry field } & \multicolumn{4}{|c|}{ Crops } & \multicolumn{5}{|c|}{ Ratio by sales method } \\
\hline & & \multirow{2}{*}{$\begin{array}{l}\text { Area } \\
\text { (a) }\end{array}$} & \multicolumn{3}{|c|}{ Number of farmland lots } & \multirow{2}{*}{$\begin{array}{l}\text { Area } \\
\text { (a) }\end{array}$} & \multicolumn{3}{|c|}{ Number of farmland lots } & \multicolumn{2}{|c|}{ Main season crops } & \multicolumn{2}{|c|}{ Secondary crops } & \multirow{2}{*}{$\begin{array}{l}\text { Peddling } \\
\text { activities }\end{array}$} & \multirow{2}{*}{$\begin{array}{l}\text { Vegetable } \\
\text { vending } \\
\text { machine }\end{array}$} & \multirow{2}{*}{$\begin{array}{l}\text { Noichi } \\
\text { (farmer's } \\
\text { market) }\end{array}$} & \multirow{2}{*}{$\begin{array}{l}\text { Retail } \\
\text { store }\end{array}$} & \multirow{2}{*}{$\begin{array}{c}\text { Co-ope- } \\
\text { ratives }\end{array}$} \\
\hline & & & Inside & Inside & Inside & & Inside & Inside & & & & & & & & & & \\
\hline \multirow{4}{*}{ } & 1 & 20 & 0 & 1 & 0 & 80 & 0 & 5 & 0 & O & $O(25)$ & O & - & 8 & 1 & 0 & 1 & 0 \\
\hline & 7 & 0 & 0 & 0 & 0 & 80 & 3 & 5 & 0 & - & $\bigcirc(23)$ & O & $O(1)$ & 6 & 0 & 2 & 0 & 2 \\
\hline & 18 & 15 & 2 & 0 & 0 & 20 & 2 & 0 & 0 & O & $O(10)$ & O & $\bigcirc(3)$ & 10 & 0 & 0 & 0 & 0 \\
\hline & 42 & 0 & 0 & 0 & 0 & 128 & 4 & 6 & 0 & - & $O(12)$ & 0 & $O(10)$ & 5 & 0 & 0 & 5 & 0 \\
\hline \multirow{4}{*}{ 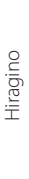 } & 48 & 70 & 4 & 2 & 0 & 47 & 5 & 0 & 0 & O & $O(27)$ & - & $O(27)$ & 8 & 0 & 2 & 0 & 0 \\
\hline & 50 & 100 & 1 & 0 & 0 & 100 & 1 & 0 & 0 & 0 & $O(23)$ & - & $O(10)$ & 5 & 0.5 & 1.5 & 0 & $1^{*}$ \\
\hline & 53 & 105 & 0 & 3 & 3 & 70 & 1 & 4 & 0 & 0 & $O(30)$ & - & $O(14)$ & 8 & 1 & 1 & 0 & 0 \\
\hline & 55 & 45 & 1 & 0 & 0 & 80 & 1 & 0 & 0 & 0 & $O(30)$ & - & $O(20)$ & 4.5 & 0 & 4.5 & 0 & 1 \\
\hline
\end{tabular}

boring lands as dry fields for vegetables and remote lands for rice fields.

In both the Kamigamo and Hiragino areas, farmers generally cultivate 10 to 30 vegetables during the summer season. For the winter season, suguki is important in the Kamigamo area while a wide variety of vegetables are produced in the Hiragino area. Almost every farmer combines peddling activities with other sales methods. Household number 50, for example, sells its vegetables at a noichi, to a cooperative society, and at vegetable vending machines.

\section{Farming activities, peddling routes, and peddling territories of sample households}

Below I describe the farming activities, peddling routes, and peddling territories of peddling households based on detailed interview surveys of several women peddlers in the Kamigamo district. With these descriptions, I indicate the characteristics of vegetable peddling by women in the Kyoto area.

\section{Case study of household 7}

A husband and wife, both in their fifties, are mainly engaged in farming activities, with his mother, who is in her eighties, being engaged as an auxiliary. The husband and wife became acquainted and got married when they were employed in the same company. In 2002, they retired from that company and began farming because the husband's father had recently died and his mother was growing old.

They grow 23 types of vegetables for peddling activities. The wife started peddling with her mother-in-law in 2003 to learn about peddling. Beginning in 2006, she peddled alone and added new customers to the customers she inherited from her mother-in-law. At that time, she reorganized her peddling routes to visit her customers more efficiently. There are three main routes for her peddling that cover all of her customers once per week.

Figure 4 shows her peddling routes. She leaves her house at approximately 7:00 a.m. and finishes at approximately 1:00 p.m. On Mondays, Thursdays, and Saturdays, she goes down Horikawa Street. On Mondays, she mainly visits her regular customers around the intersection of Shijo and Nishioji Streets. On Thursdays, she visits her regular customers in the Uzumasa area (around Route 132). On Saturdays, she visits her customers on Imamiya Street, Nakadachiuri Street, Shimochoja Street, and Demizu Street. On Saturdays she also visits her customers on the north side of Saiin Station and near the Nisshin Electric factory. On the other hand, on Wednesdays she goes down Karasuma Street and visits her regular customers in the northwestern area near the Kyoto Imperial Palace. The customers she visits on Wednesdays and Saturdays are mainly old customers she inherited from her mother-in-law. They are often very old, in their eighties or nineties. Sometimes, she stops visiting if her customers are not home several times in a row.

When customers are close together, she parks her pickup truck and knocks on the doors of several customers living nearby. If an individual customer lives far from other customers, she stops her truck in front of the customer's house. She usually visits her regular customers on the same day of the week at the same time. Some customers await the arrival of their usual peddler, watering the 


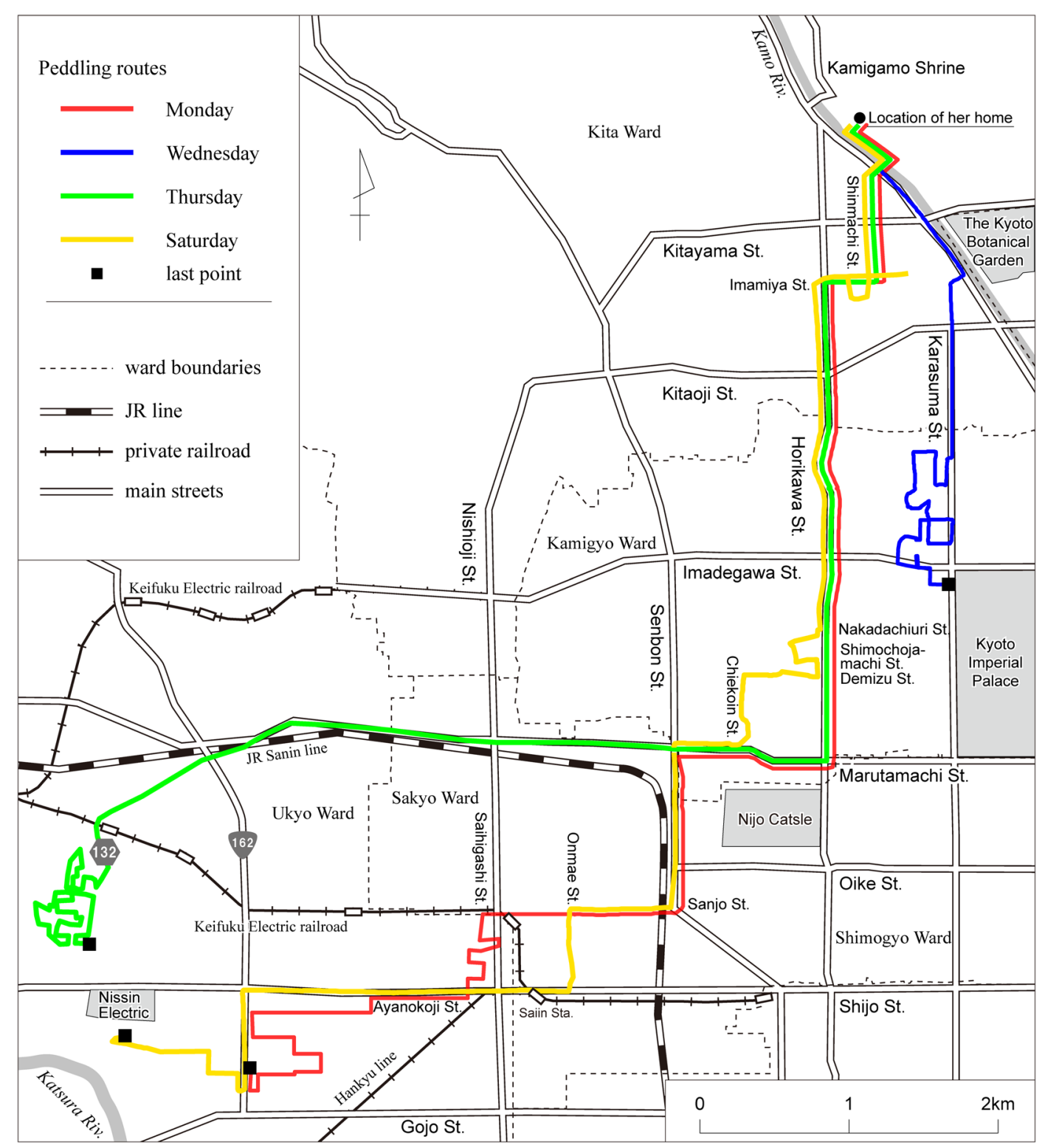

Figure 4. Peddling routes of a woman peddler (household number 7).

Source: interview surveys.

street on hot summer days, and other customers complain if her arrival is delayed. After knocking on her customers' doors, she stands by her truck and waits for them; they typically come outside and meet her with baskets or plastic bags for carrying their vegetables.

Her customers are always women. They exchange greetings and chat with each other around the truck, picking up the vegetables to examine the quality. When the customer decides which vegetables to buy and in what quantity, she puts the vegetables into her own basket or plastic bag. The peddler calculates the total price and hands over a memo showing the amount. The customer then goes back into her home with the basket or bag and comes out again with her wallet. Sometimes customers give her small presents such as pickles or handcrafted articles. The peddler helps the elderly women carry the vegetables back to their homes. Sometimes customers ask how to cook the vegetables. For this reason, the peddler often cooks a variety of vegetable dishes at home so she can teach her customers how to cook the vegetables she grows.

Some customers invite her into their homes and entertain her with tea and sweets or give her souvenirs from their travels. In return, she often buys souvenir articles for her customers when she travels. With certain customers with whom she has more friendly relationships, she exchanges gifts, especially on their families' ceremonial occasions. It is very important for her to maintain good relationships with her regular customers.

She believes most customers wait for her to purchase their vegetables. However, among her customers, there are some who purchase vegetables unwillingly. She does 
not visit those customers when her commodities are insufficient. She takes special care of customers who always purchase her commodities. Sometimes when she stops her truck to sell vegetables, an unknown person approaches and talks to her, and she may gain a new regular customer.

It is a unwritten rule among women peddlers that they avoid any overlapping of peddling territories. Some customers ask, "How is your mother?" (meaning her motherin-law). Since they (and their mothers-in-law as well) had bought vegetables from the peddler's mother-in-law, they do not buy vegetables from other peddlers. But some customers also purchase vegetables from other peddlers. Because she only peddles from April to August (around the Bon, or Urabon festival), her regular customers must purchase vegetables from other peddlers or in the supermarkets during the off months. In late July, her customers worry about her last visit. When she finishes harvesting all the vegetables from her farmlands, she informs her customers that it is her last peddling for that year, and she explains the schedule for the next year.

Her customers indicate various reasons for always purchasing vegetables from peddlers: they say that peddling vegetables are fresh and safe to eat, they are well acquainted with the cultivator, and many of them have purchased vegetables from women peddlers for a long time. One customer in her eighties said it is very natural to buy vegetables, fish, and various commodities from peddlers.

The peddler recognizes her customers mainly by their faces, not their family names. She does not know how many customers she has. Her vegetables are priced slightly lower compared to nearby supermarkets. Generally, she does not change her prices during her peddling activities from April to August.

Figure 5 shows the cultivation calendar for crops on her farm. Her husband is mainly engaged in the cultivation of crops. She is also involved in farming with her husband in addition to peddling. To start peddling vegetables in the middle of April, they plant strawberries and sow green peas (snow and snap peas) at the end of October. Up until January, working days on peddling crops occupy just less than half of all days, but after February they must work almost every day on their farmland. They sow and scatter manure and water in March, and based on the degree of growth, they replant the crops. They sow and replant the same crops repeatedly so that they can harvest vegetables over a longer period. In April, they harvest a little of each vegetable and cook it to determine the harvest time for each farmland lot. The opening day of peddling activities is decided by this kind of preparation.
During the peddling period, she informs her husband about the sales of each vegetable type. This transfer of information between wife and husband is important because her husband adjusts the quantity of harvested vegetables for the next peddling based on her report. Vegetables for peddling are generally harvested on the preceding day, except vulnerable vegetables such as tomatoes, cucumbers, eggplants, and lettuces. After harvesting, they divide each kind of vegetable into small plastic bags of the same weight. When the harvests of tomatoes, eggplants, and cucumbers are too large for peddling, they carry the remaining vegetables to a farmer's market (noichi). On her farm, only kamonasu (a special kind of eggplant) is sold through a cooperative society. For joint shipments, size and color standards must be met. Nonstandard vegetables are sold at lower prices through peddling. Sometimes, vegetables in poor condition or from surplus harvests are offered free of charge for her regular customers.

After finishing the harvest of peddling crops, the peddler and her husband prepare their dry fields for the next suguki cultivation. Figure 6 shows the cultivation calendar for suguki. Suguki cultivation starts in September and ends in December. The couple grows suguki on six of their eight lots. From the beginning of September to the middle of the month, they sow the suguki seeds; then they thin, weed, and water the crop almost every day in October. From the beginning of November to the middle of December, the harvesting and processing of suguki are carried out every day. They employ part-time workers during this period. Every day, they harvest suguki in the morning, pare the skin of the suguki in the afternoon, and soak it in a large salt-filled barrel overnight. The next morning, the suguki is washed by hand and moved again to a salted barrel.

From the end of December (or the beginning of January) to the beginning of March, the suguki is transferred to a room kept at $40^{\circ} \mathrm{C}$ and left for one week for lactic acid fermentation. This household wholesales completed suguki pickles to a pickle company in Kyoto. They gather the seeds of nonharvested suguki on their own fields in the middle of May and utilize them for the next cultivation.

\section{Case study of household 48}

The second case study examined a household in the Hiragino area. In this household, a husband and wifewho were in their sixties and fifties, respectively-are mainly engaged in farming. The man's father, who is in his eighties, assists them. Their son, who is in his twenties, is involved in the water cultivation of tomatoes, and 


\begin{tabular}{|c|c|c|c|c|c|c|c|c|c|c|c|c|c|c|c|c|}
\hline & Growing Crops & Sep. & Oct. & Nov. & Dec. & Jan. & Feb. & Mar. & April & May & June & July & Aug. & Seeding & Shipping & $\begin{array}{c}\text { Cultivation } \\
\text { Types }\end{array}$ \\
\hline 1. & $\begin{array}{c}\text { Japanese Mustard } \\
\text { Spinach }\end{array}$ & & & & & & & $\Delta$ & $\Delta=$ & & & & & 2 & - & Open Field \\
\hline 2 & Strawberry & & $\bullet$ & & & & $\mathbf{W}$ & $N$ & -1 & $\begin{array}{ll}1 \quad 1 \\
\longrightarrow\end{array}$ & & & & - & - & Greenhouse \\
\hline 3 & Small Turnip & 1 & & & & & $\begin{array}{c}1 \\
\vdots\end{array}$ & $\Delta$ & - & + & & & & 1 & - & Open Field \\
\hline 4 & Potherb Mustard & $\begin{array}{l}1 \\
\vdots\end{array}$ & & & & & $\begin{array}{c}21 \\
1 \\
1\end{array}$ & $\mathbf{\Lambda}$ & $\Delta$ & 1 & & & & 2 & - & Open Field \\
\hline 5 & Onion & $\Delta$ & $T$ & & $\bullet$ & $\bullet$ & $\mathbf{w}$ & $\begin{array}{l}71 \\
\end{array}$ & - & 1 & & & & 1 & - & Open Field \\
\hline 6 & Spinach & & & & & & $\Delta$ & & $\Delta=$ & $1 \quad 1$ & $\stackrel{1}{\longrightarrow}$ & & & 2 & - & Open Field \\
\hline 7 & Peas & & $\Delta$ & $\Delta$ & $R$ & $\bullet$ & $\mathbf{N} \mathbf{H}^{\prime}$ & 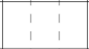 & & 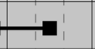 & & & & 2 & - & Open Field \\
\hline 8 & Snap Garden Peas & & $\Delta$ & $\Delta$ & $R$ & $\bullet$ & $N$ & $\mathrm{H}$ & & $\longrightarrow$ & & & & ? & O & Open Field \\
\hline 9 & Lettuce & & & & & $\Lambda$ & $\begin{array}{l:l}T & T \\
\end{array}$ & $\bullet \bullet \bullet$ & 0 & $1 \quad 1$ & $\rightarrow$ & & & 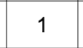 & - & Greenhouse \\
\hline 10 & Red Leaf Lettuce & 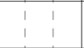 & & & & $\Delta$ & $\begin{array}{l:l}\mathbf{T} & \end{array}$ & $\bullet \bullet \bullet$ & $\bullet$ & \begin{tabular}{|l|l|l|} 
& 1 \\
& 1 \\
\end{tabular} & $\rightarrow$ & & & 1 & 0 & Greenhouse \\
\hline 11 & Cucumber & 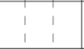 & & & & & $\begin{array}{l}1 \\
1 \\
1\end{array}$ & $\bullet$ & $H^{\prime}$ & $\begin{array}{r:}1 \\
1 \\
\end{array}$ & $\bullet$ & 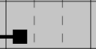 & & - & 0 & Greenhouse \\
\hline 12 & $\begin{array}{c}\text { Japanese Radish } \\
\text { (long type) }\end{array}$ & & & & & & \begin{tabular}{|l}
1 \\
1
\end{tabular} & $\Delta \mathbf{A}$ & & 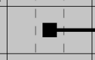 & & & & 4 & 0 & Greenhouse \\
\hline 13 & Kidney beans & 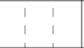 & & & & & G & $H$ & $\mathrm{H}$ & $\mathrm{H}$ & 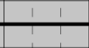 & $\rightarrow$ & & 3 & - & Greenhouse \\
\hline 14 & Red Pepper & $\vdots$ & & & & & $G$ & $\bullet$ & & - & & 1 & $\rightarrow$ & - & - & Greenhouse \\
\hline 15 & Tomato & & & & & & 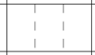 & $\bullet$ & $\mathrm{P} \dot{\mathrm{H}}$ & - & & & $\rightarrow$ & - & - & Greenhouse \\
\hline 16 & Eggplant & . & & & & & ! & $\bullet$ & $\mathbf{P}$ & - & & & - & - & - & Greenhouse \\
\hline 17 & Kamo Eggplant & 1 & & & & & $G$ & $\mathbf{T} \bullet$ & & - & 1 & 1 & $\rightarrow$ & - & 0 & Greenhouse \\
\hline 18 & Potato & 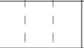 & & & & & $\begin{array}{l}1 \\
1 \\
1\end{array}$ & $\Delta$ & & & - & & & 1 & - & Open Field \\
\hline 19 & Green Onion & $\bullet$ & & & & - & $\begin{array}{l}31 \\
1 \\
1\end{array}$ & & & & - & & & - & 0 & Open Field \\
\hline 20 & Okra & & & & & & $\begin{array}{l}2 ! \\
\vdots\end{array}$ & & $\Delta$ & - & - & & & 1 & - & Open Field \\
\hline 21 & Green Soybeans & & & & & & ! & $\mathbf{\Lambda}$ & - & $\bullet$ & - & $\rightarrow$ & & 3 & - & Open Field \\
\hline 22 & Pumpkin & & & & & & $\begin{array}{l}1 \\
1 \\
1\end{array}$ & $\mathbf{\Lambda}$ & 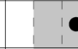 & $\mathrm{H}$ & & $\rightarrow$ & & 1 & - & Greenhouse \\
\hline 23 & Perilla & & & & & & $\begin{array}{l}1 \\
\vdots \\
\end{array}$ & 1 & $T$ & $\bullet$ & & $\stackrel{1}{1} \quad 1$ & & - & - & Open Field \\
\hline 24 & $\begin{array}{c}\text { Seedling } \\
\text { (Green Onion) }\end{array}$ & $\Delta$ & 11 & 11 & $T$ & + & \begin{tabular}{r|r}
1 \\
1 \\
1 \\
\end{tabular} & $\begin{array}{ll}1 \\
\vdots \\
\end{array}$ & 1 & $\begin{array}{ll}1 \\
1 \\
1\end{array}$ & 1 & $\begin{array}{l}1 \\
\vdots \\
\end{array}$ & D & 1 & - & Open Field \\
\hline 25 & $\left|\begin{array}{c}\text { Japanese Radish } \\
\text { (round type) }\end{array}\right|$ & $\Delta$ & & & & - & $\begin{array}{c:c} & 1 \\
\vdots & 1 \\
\end{array}$ & $\begin{array}{ll}1 & 1 \\
\vdots & 1 \\
1 & 1\end{array}$ & & $\begin{array}{l:l} & 1 \\
\vdots & \end{array}$ & $\begin{array}{ll}1 & 1 \\
1 & 1 \\
1 & 1\end{array}$ & $\begin{array}{lll} & 1 \\
\vdots & 1 \\
1 & 1\end{array}$ & & 1 & 0 & Open Field \\
\hline
\end{tabular}

$\boldsymbol{\Delta}$ : seeding $\mathbf{O}$ : planting $\mathbf{\square}$ : harvest

P: pruning D: drying
$\mathrm{N}$ : net drawing $\quad \mathrm{H}$ : hanging $\quad \mathrm{R}$ : replanting $\quad \mathrm{T}$ : transplanting

season of vegetables peddling

Figure 5. Cultivation calendar of crops in household number 7 (September 2008 to August 2009).

* — indicates that seedlings are purchased.

** $\bigcirc$ indicates shipping to destinations other than peddling.

Source: interview surveys and farmer's diary.

\begin{tabular}{|c|c|c|c|c|}
\hline \begin{tabular}{|l|} 
land \\
lot \\
\end{tabular} & $\begin{array}{l}\text { September } \\
5 \quad 10 \quad 15 \quad 20\end{array}$ & $\begin{array}{c}\text { October } \\
5 \quad 10 \quad 15 \quad 2025\end{array}$ & $\begin{array}{l}\text { Novembe } \\
\begin{array}{l}5 \quad 10 \quad 15 \quad 20\end{array}\end{array}$ & $\begin{array}{l}\text { December } \\
5 \quad 10 \quad 15 \quad 20 \quad 25\end{array}$ \\
\hline A & $\Delta \quad 101$ & 11 & $\square$ & \\
\hline B & 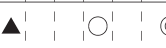 & ! & \begin{tabular}{l|l|l} 
& 1 & $\mid$ \\
1 & 1 & 1
\end{tabular} & \\
\hline$C$ & $\triangle \quad 101$ & (a) 1 & 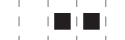 & \\
\hline D & $\begin{array}{l:l:l} & \mathbf{\Lambda}_{1}^{\prime} & 1\end{array}$ & : & ! & $\square$ \\
\hline E-1 & $\Delta \quad 10$ & () & 1 & $\mathbf{a}$ \\
\hline E-2 & $\mathbf{\Delta}_{1}^{\prime}: \mathrm{O}_{1}^{\prime}$ & :@! & ! & $\boldsymbol{\nabla}: \mathbf{Q}^{\prime}$ \\
\hline $\mathrm{F}$ & 10 & (1) & 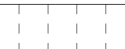 & a \\
\hline
\end{tabular}

$\Delta$ : sowing $\bigcirc$ : thinning out $($ ): last thinning out $\mathbf{\square}$ : harvest

Figure 6. Cultivation calendar of suguki in household number 7 (September to December 2008).

Source: interview surveys and farmer's diary.

his wife, also in her twenties, is in charge of housekeeping and childcare. The man in his sixties began farming with his parents immediately after graduating from an agricul- tural high school in 1968. His wife was born in the same village and married him in 1976 when she was 24 . Since her parents were also engaged in farming and peddling, she was familiar with peddling activities from her childhood.

After her marriage, she gave birth to two children, the first in 1979 and the second in 1982. During the 1980s, therefore, she was engaged in farming only as an assistant. At that time, her father-in-law, mother-inlaw, and her husband were the main farm workers. In 1991, she began to help her mother-in-law with peddling activities using a two-wheeled cart. The mother-in-law stopped peddling in 1994 and died at the age of 70 in 1996. Usually, when peddling activities are passed from the mother-in-law to the daughter-in-law, childcare and housekeeping become the responsibility of the mother- 
in-law. In this case, however, since the mother-in-law died, the daughter-in-law had to carry out housekeeping, childcare, farming, and peddling responsibilities simultaneously. After her son married in 2007, it became somewhat easier because her son's wife shared housekeeping responsibilities.

After taking over the peddling route from her motherin-law, she gained new customers by herself. Her peddling route, however, is not very different from her mother-in-law's. From April to August, she goes to central Kyoto three times a week for her peddling activities since many vegetables can be harvested during this period. However, during other seasons-the rice-planting season and the winter season, for example-she generally peddles vegetables two times a week. She follows the same peddling route and visits the same customers every time.

Figure 7 shows her peddling route. She leaves her house at 9:00 or 10:00 a.m. and returns at approximately 8:00 p.m. in the summer and 6:00 p.m. in the winter. First, she follows Prefecture Route 61 and visits her customers near the Hiragino elementary school and in Nakayamacho and Umanomecho. From there, she returns via the same street to Shikuro Bridge and crosses the Kamo River to visit customers near the Nishigamo junior high school and in Kanigasakacho. Then, she crosses

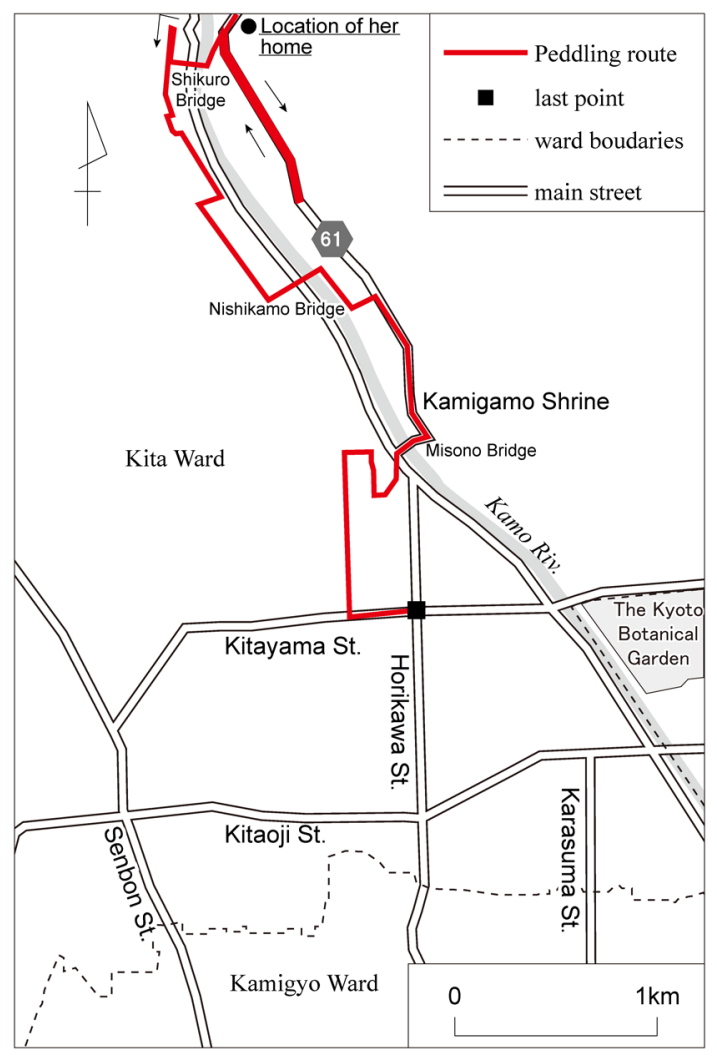

Figure 7. Peddling route of a woman peddler (household number 48).

Source: interview surveys. the Kamo River again on the Nishigamo Bridge to visit customers near the Kamigamo Shrine. She crosses the Kamo River once again on the Misono Bridge and goes to Kamihorikawacho and Uenokishicho. Finally, she goes to Kitayama Street, where her route ends at the intersection of Horikawa and Kitayama Streets. Her mother-in-law, however, followed Prefecture Route 61 to Misono Bridge. After crossing the Kamo River, her mother-in-law visited customers along Horikawa Street and Omiya Street. Thus, their peddling routes are similar. In looking for new customers, she always takes care to avoid overlapping any territory covered by other peddlers.

Like the woman peddler in the previous case study, she is sometimes invited into customers' homes and entertained with tea and sweets. In return, she always purchases small souvenirs for her customers when she travels. She considers some of her customers close friends. She takes great pleasure in spending time with them on her peddling route. On family ceremonial occasions, she and her customers exchange gifts. When her customers move to other places, she occasionally sends vegetables to them. Such relationships clearly go far beyond the ordinary merchant-customer relationship. In general, however, she never interacts with her customers outside of her peddling activities.

Her customers include very old households whose family members purchased vegetables from her grandmother-in-law. She takes special care of these customers. Similar to the woman peddler in the previous case, she recognizes her customers not by their names, but by their houses and faces. She refers to supermarket prices when setting her vegetable prices. After finishing her peddling activities, she always informs her husband about the sales for each kind of vegetable so he can adjust the cultivation plans for the next crop.

Figure 8 shows the cultivation calendar for the vegetables household 48 grows for peddling. There are no less than 15 kinds of vegetables from spring to summer, and no less than 16 kinds from autumn to winter. In addition to these vegetables, they sow Japanese radish (long type), lettuce, and red leaf lettuce six times per year and sell these crops from October to June. In addition to these 33 kinds of vegetables, they also grow various green vegetables for salads, such as kyona, mibuna, Japanese mustard spinach, wasabina, ching guang juai, salad mustard (frill green and frill red), rocket salad, and red stem spinach, among others. Peddling activities for this household are carried out continuously year round. They have no income from real estate. Therefore, they grow as many kinds of vegetables as possible to increase the variety of 


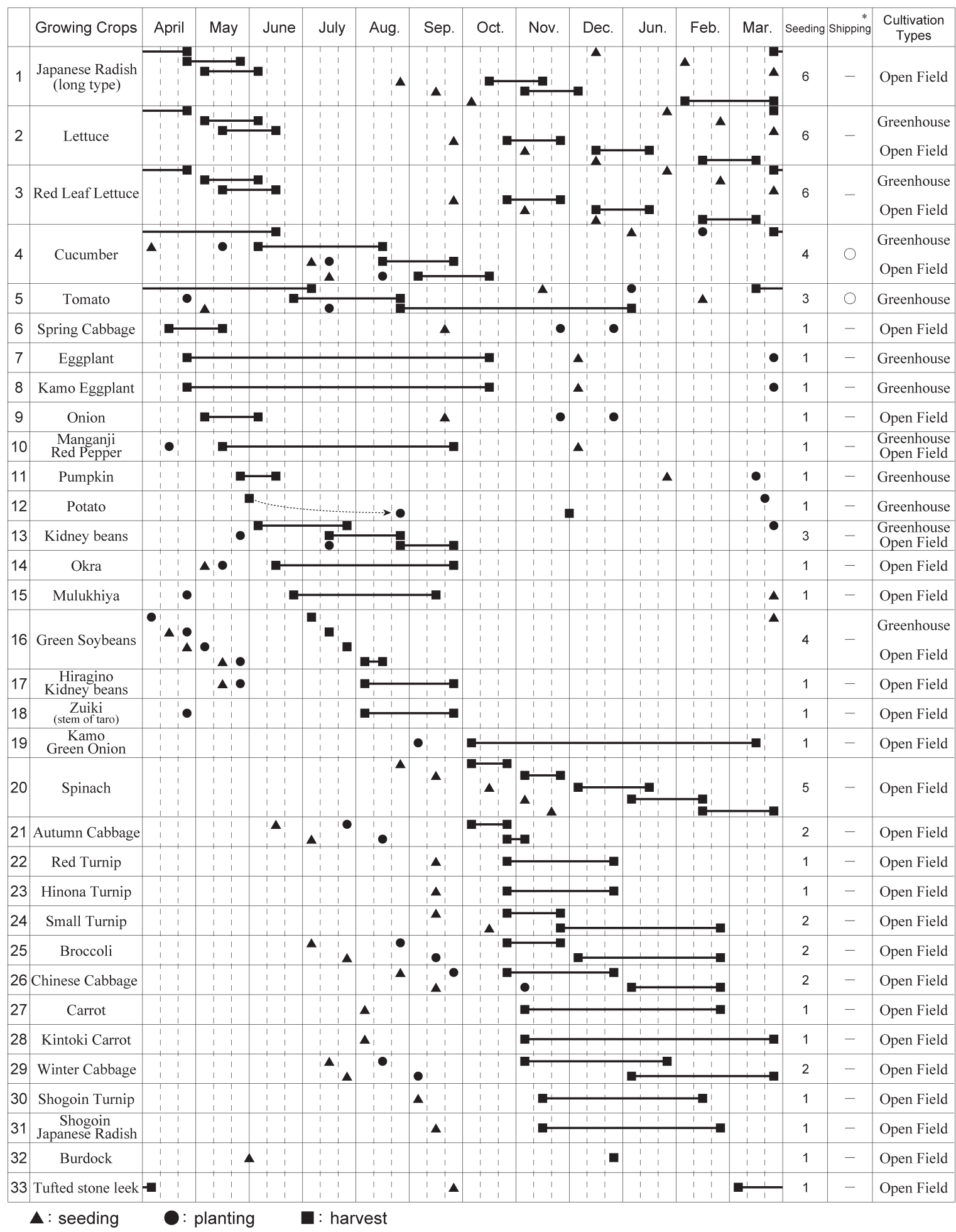

Figure 8. Cultivation calendar of crops in household number 48 (April 2010 to March 2011).

* $\bigcirc$ indicates shipping to farmers' markets.

Note: In addition to these crops, kyona, mibuna, Japanese mustard spinach, wasabina, ching guang juai, salad mustard (frill green), salad mustard (frill red), rocket salad, and red stem spinach are grown during a year.

Source: Interview surveys.

vegetables available in any season. At the same time, her husband has a determined attitude toward the taste and quality of his products. He has won many prizes in vegetable fairs in Kyoto City. He laments "I cannot harvest at the true seasonal time of crops" because it is necessary to carry many kinds of vegetables to the city each time to satisfy customer needs. But, he thinks that preferably he would like to provide his vegetables at the time when each crop is the most delicious. 


\section{Discussion}

Based on the above, the four basic characteristics of the peddling activities in Kamigamo district are as follows:

The first characteristic is that peddling activities are carried out by women, and agricultural work is done by their husbands. Labor division can be seen. Since the men do the work requiring strength, the women do the peddling activities. In Kamigamo district, agricultural machines were introduced in the late 1950's to the 1970's. Before the introduction of machines, agricultural work was very hard work, therefore, men did the agricultural work and women did the peddling activities. The custom turned gradually, as a form of inheritance, for the peddling work to be handed down from a woman to her daughter-in-law, even after the 1970's, when agricultural machines were introduced, so that even now, women do most of the peddling activities. The peddlers pass their work on to their daughters-in-law, and customers tell their daughters-in-law to use these peddlers since the customers are accustomed to dealing with them, making it difficult for men to participate in the peddling activities.

The second characteristic is that the peddling activities were important to complement the income from rice farming as the peddlers could get money immediately. The average area of farmlands owned by all the peddling farmers in Kamigamo district was 0.44 ha in 1960 which was after the agricultural reform. It is 0.51 ha at present. The farmland in the suburban areas of Kyoto is usually small, and it was difficult to maintain a living only from the income from rice farming, resulting in the necessity to supplement their income with peddling vegetables.

The third characteristic is that peddling was a singleday activity. The peddling activities in the suburban areas of Kyoto involved production activities conducted in residential areas. The peddling activities were carried out in areas where the peddlers could sell all of their products and return home on the same day. At present, pick up trucks are used for transportation in Kamigamo district. The peddling territory has expanded compared to the days when peddling activities were carried out on foot by pulling a two-wheeled cart, but peddling is still a singleday activity.

The final characteristic is the trust relationship established between the peddlers and their customers, which goes beyond the commercial act of exchanging products and money. The women peddlers in Kamigamo district supply odd-shaped vegetables to customers for free, and receive sweets and gifts from their customers in return. There is a tacit understanding that peddlers do not steal each other's customers. The women peddlers do their peddling activities regardless of the weather or their own physical condition, and they adjust their time without staying with one customer for too long so that they can visit their other customers at the same time each visit. They pay close attention to keeping the trust relationship that they have with each customer. This trust relationship established between the peddlers and customers is a strong motivation for the continuance of the custom of the peddling activities.

The above four characteristics have been pointed out in previous studies and are not limited to just the peddling activities in Kamigamo district. However the following section, focusing on agriculture in Kamigamo district, will clarify why the peddlers still exist in Kamigamo district.

The characteristics common among peddling farmers in Kamigamo district are that their farmlands are small because they are located in the suburban areas of Kyoto, and they can grow only small amounts, but many types of vegetables, on those lands. The farmers in Kamigamo district cannot grow large amounts of one type of vegetable, so it is not suitable for joint shipping. This is the reason why the peddling activities are used as the major means for selling their products, even in modern times, when the distribution mechanisms are well arranged. The important point is that these peddling farmers in Kamigamo district have maintained small farmlands and continue producing even while urban land use has expanded in the suburban areas in Kyoto. This can be explained by two reasons. As Hayashi (1963) pointed out, one reason is that agricultural management became stable by dramatic development of suguki from the Taisho Period to early in the Showa Period. The ratio of practical farmers in 1956 was 8\% in Matsugazaki district, which is located adjacent to Kamigamo district, and $88 \%$ in Kamigamo district. The second reason is that earnings become stable by income from real estate. The farmlands in Kamigamo district decreased due to the land readjustment project in the 1960's, and acquisition of lands by a university. However, the farmers gained income from real estate by managing apartments and succeeded in maintaining agricultural management by purchasing farmlands outside of Kamigamo district, as well as stabilizing family finances. As the peddlers in Kamigamo district grow all of the vegetables sold through peddling, maintaining agricultural management is the most important condition for the peddling activities.

The other characteristic of agriculture in Kamigamo district is that the peddling famers in Kamigamo dis- 
trict grow many types of traditional vegetables, which are closely connected to the daily food of general people in Kyoto. Vegetables including zuiki (stem of taro) and Hiragino Kidney beans are used for seasonal traditional foods in Kyoto, and vegetables such as Kamo Eggplant, Manganji Red Pepper and Shogoin Turnip are used for daily food in Kyoto. Connection between the growth and selling of those traditional vegetables and the food culture in Kyoto, is one of the most important factors of the continuing of the peddling activities in Kamigamo district. As Kyoto City is located inland, a culture highly dependent on vegetables was established. Suguki, grown in the Kamigamo area is a vegetable that is not allowed to be grown outside of the Kamigamo area and is a traditional vegetable. This enables the maintenance of the agricultural management of the peddling farmers in the Kamigamo area.

\section{Conclusion}

This article considers the changing peddling practices in Kamigamo area, where a number of farmers produce traditional vegetables called Kyoyasai (traditional and local vegetables grown in and around Kyoto). These traditional products are mainly sold to customers in a very particular way: peddling, the way historically succeeded by local women of farm households. The research was mainly based on interviews with peddlers in the study area, especially focusing on the inheritance process of the peddling system, the changing farming management, the roles of their husbands who produce vegetables, and the impact of changing means of transportation related to the expansion of peddlers' trading area. The factors affecting their decision-making process are also analyzed. The results of this article are summarized in major points.

At first, I indicated the characteristics of the peddling activities in Kamigamo district: 1) Peddling is mainly carried out by women, and agricultural work is done by their husbands. Both the peddlers and customers pass their work on to their daughter-in-law, making it difficult for men to participate. 2) Peddling activities were important to complement the income from rice farming as the peddlers could get money immediately. 3) Peddling is a single-day activity. The peddling activities in the suburban areas involved production activities in residential areas. 4) The trust relationship establishes between the peddlers and their customers beyond the commercial act.

Secondly, I analyzed the characteristics of agriculture in Kamigamo district: 1) Kamigamo district is located in the suburban area of Kyoto, therefore the farmlands owned by the peddlers are small. Small amounts of various vegetables are grown. 2) The peddling farmers grow various traditional vegetables.

Finally, I clarified that the factors contributing to continued peddling activities are: the peddling farmers maintain small farmlands and continue their agricultural work while urban land use has expanded; and the traditional vegetables that the peddling farmers grow are closely connected to the daily food of ordinary local people.

\section{Acknowledgements}

A summary of this paper was presented at the general meeting of the Association of Japanese Geographers at Tokyo Metropolitan University in March 2012. I appreciate the people who provided me with valuable materials and information in my field survey in Kamigamo district. I greatly appreciate Professor Akira Tezuka and other academic staffs of the Graduate School of Life and Environmental Sciences at the University of Tsukuba. Also, I am grateful to Professor Hideo Uno of the Kyoto City Historical Museum. This study was supported by Scientific Research by JSPS (DC2) 21701.

\section{Notes}

1. Furiuri is a method of selling without standing stores. It was actively used from the Middle Ages to the Edo Period. Men carried commodities with tenbinbo on one shoulder while women often carried commodities on their head and sold them along their itinerant routes (Sakurai 1991). Since the Meiji Period, furiuri often indicates itinerant sales with two-wheeled carts.

2. There are two types of peddling activities. One is long-distance peddling between peddlers' villages and market areas, and the other is small-scale peddling within one day's travel (Sasaki 1983). With the latter form of peddling, production and selling are usually performed by the same household. Peddling in a narrow sense signifies the former. Peddling by women usually belongs to the latter form of peddling.

3. Otagi gun son shi belongs to the Kyoto Prefectural Library and Archives. This document was compiled to provide basic materials for the writing of Kokoku chishi; village topographies edited by the Ministry of Home Affairs around the 1880's. Otagi county was among the eight counties of the Yamashiro no kuni (Otagi, Kadono, Otokuni, Kii, Uji, Kuze, Tuzuki, and Soraku).

4. According to Hayashi and Iwaki (1988), junsai in the Midorogaike Pond was famous during the Edo Period as a foodstuff in Kyoto cuisine, and it was harvested until approximately 1965.

5. It is unknown whether it was the same in the Hiragino area.

6. Collection of organic manure was mainly carried out by men. Collected organic manure was stored in a large hole (called a notsubo) dug in the farmlands.

\section{References}

Amino, Y. 1973. Characteristics of $u k a i$ in the Middle Ages: Katsu- 
rame and ukai. Japanese History 135: 1-23. (J)

Aono, H. 1932. Kujukurihama ni okeru suisangyo no chirigakuteki kenkyu: Kujukurihama kaigan heiya no chishigakuteki kenkyu (1) (A geographical study on fishery in Kujukurihama: Topographical study on seaside plain in Kujukurihama, no. 1). Journal of Geography (Chigaku Zasshi) 44: 611-620. (J)

Aono, H. 1933. Kujukurihama ni okeru suisangyo no chirigakuteki kenkyu: Kujukurihama kaigan heiya no chishigakuteki kenkyu (2) (A geographical study on fishery in Kujukurihama: Topographical study on seaside plain in Kujukurihama, no. 2). Journal of Geography (Chigaku Zasshi) 45: 37-48. (J)

Hashimoto, A. 2007. Transformation of female firewood traders from 1890's to 1950's: Comparative study of Ohara and Yase, Kyoto. Historical Review of Transport and Communications 63: 29-51. (J)

Hashimoto, A. 2011. Peddling activities of firewood sellers in the suburbs of Kyoto: Case study of Yase and Ohara villages from the 1870 to the 1950s. Historical Geography 53(4): 38-56. (JE)

Hayashi, Y. 1963. Kyotoshi kinko tokusan sosaisaku no hensen katei: sono rekishiteki, chiriteki kenkyu (Changing process of cultivation of special vegetables in surrounding area of Kyoto city: Historical and geographical study). Nogyo Keizai Kenkyu Hokoku 5: 1-458. (J)

Hayashi, Y. 1966. Kyotoshi kinko sosai no ryutsu jittai (Distribution of vegetables in surrounding area of Kyoto city). Nogyo Keiei Kenkyu Shiryo 1: 1-64. (J)

Hayashi, Y. 1980. Kyoto no tokusan yasai no hensen (Changes of local vegetables in Kyoto). Nogyo to Keizai 46(8): 33-40. (J)

Hayashi, Y. and Iwaki, Y. 1988. Kyo no yasai: Aji to sodachi (Vegetables in Kyoto: Taste and cultivation). Kyoto: Nakanishiya Shuppan. (J)

Ishikawa, T. 1934. Tokyoshi oyobi sono fukin ni okeru seika no gyosho chosa (Investigation on vegetable peddlers in Tokyo city and its surrounding area). Nogyo to Keizai 1: 595-611. (J)

Iwata, H. 1984. Oharame. Osaka: Gendai Sozo Sha. (J)

Kitami, T. 1970. Ichi to gyosho no minzoku (Folklore on markets and peddling activities). Tokyo: Iwasaki Bijutsu Sha. (J)

Kobayashi, H. 2005. A shinnomi-batake in Sawara: Vegetable growing and peddling in the suburbs of a provincial city. Bulletin of the National Museum of Japanese History 124: 33-57. (JE)

Koike, Y. 1955. Kamigamo, Kyoto, a farming area within a city. Geographical Review of Japan 28: 339-353. (JE)

Kyoto City 1972a. History of Kyoto, volume 5. Kyoto: Gakugei Shorin. (J)

Kyoto City 1972b. Furiuri jittai hokoku sho (Report on peddling activities). Kyoto: Kyoto City. (J)

Kyoto City 1975. History of Kyoto, volume 8. Kyoto: Gakugei Shorin. (J)

Kyoto City 2009. Agriculture and forestry census, results of Kyoto city. Kyoto: Kyoto City. (J)

Masuzaki, K. 2000. Akinaishi in Shikanoshima district: The case of women's seafood peddlers in the suburban fishing village, Fukuoka city, Fukuoka Prefecture. Bulletin of the Folklore Society of Kyoto 18: 67-84. (J)

Mizoguchi, T. 1976. The peddling activity of the upland field villages in the Midai-gawa alluvial fan, Yamanashi Prefecture.
Human Geography 28: 141-170. (JE)

Nakamura, S. 1984. A socio-economic relationship between fishing villages and inland villages from view to sea food peddling: A case of Nago in Izumi city, Kagoshima Prefecture. In Historical Geographic Review, volume 26, ed. Association of historical geographers in Japan, 127-146. Tokyo: Kokonshoin. (J)

Nakamura, S. 1985. Spatial considerations of the behavior of seafood peddlers: The case of the San'in district, western Japan. Human Geography 37: 310-331. (JE)

Nakamura, S. 1986. Behavioral analysis of peddlers in fish producing area: A case study on Sanmiura, Hagi city, Japan Sea Coast. Geographical Sciences 41: 133-149. (JE)

Nakamura, S. 1988. Local expansion of socio-economic relations between a fishing village and the inland villages: A case of Hashima district in Kushikino city, Kagoshima Prefecture. Human Geography 40: 180-194. (J)

Ozaki, T. 1939. Tokyo eno Chibaken higaeri gyosho no chishigakuteki kenkyu (A topographical study on one day peddlers from Chiba Prefecture to Tokyo). Chirigaku 7: 187-198. (J)

Saji, F. 2008. Vegetable venders: A case study in Fukushima Prefecture. Tohoku Anthropological Exchange 7: 79-98. (J)

Sakurai, E. 1991. Furiuri (Peddling). In Kokushi dai jiten, volume 12, ed. Kokushi dai jiten henshu iinkai, 350-351. Tokyo: Yoshikawa Kobunkan. (J)

Sasaki, G. 1983. Gyosho (Peddling). In Kokushi dai jiten volume 4, ed. Kokushi dai jiten henshu iinkai, 309-310. Tokyo: Yoshikawa Kobunkan. (J)

Segawa, K. 1971. Hisame: Josei to shogyo (Hisame: Peddling activities by women). Tokyo: Mirai Sha. (J)

Shimizu, K. 1954. The outset of the bicycle peddling of raw fish in Kujukurihama and its selling sphere: Change in fishing settlements with the advance of transport facilities. Human Geography 5: 434-480. (JE)

Tabata, Y. 1998. Oharago to Oharame (Ohara district and Oharame). In Ie to josei no shakaishi (Social history of home and women), ed. Kyoto Tachibana Women's University (Institute of History and Culture of Women), 41-68. Tokyo: Nihon Editor School. (J)

Takano, A. 2009. Kindai toshi no keisei to zainichi chosenjin (Evolution of modern cities and Koreans in Japan). Kyoto: Bukkyo University. (J)

Tamura, U. 2006. Furiuri: Toshi ni ikizuku yasai gyosho (Furiuri: Present vegetable peddlers in Kyoto City). In Fuirudowaku e no chosen (Challenge to fieldwork), ed. K. Sugawara, 169-191. Kyoto: Sekai Shiso Sha. (J)

Uemura, Y. 2004. Takagamine chiiki no kukan henyo: sangyo to toshika (Spatial changes in the Takagamine district: Industry and urbanization). In Kyoto Murasakino, Takagamine no chiiki bunka gaku: Bukkyo daigaku Murasakino kochi gakujutsu chosa hokoku sho 2004 (Culture-study on the Murasakino and Takagamine districts: Examination reports of Bukkyo University), ed. Bukkyo University, 73-79. Kyoto: Bukkyo University. (J)

(J) written in Japanese

(JE) written in Japanese with English abstract 